\title{
Pengaruh Teknologi Informasi, Partisipasi Manajemen, Kemampuan Pemakai SIA, Pendidikan dan Pelatihan Pada Kinerja Manajemen LPD
}

\author{
Ni Komang Diana Pradasari ${ }^{1}$ \\ Ida Bagus Dharmadiaksa ${ }^{2}$ \\ ${ }^{1}$ Fakultas Ekonomi dan Bisnis Universitas Udayana (Unud), Bali, Indonesia \\ e-mail: pradasaridiana07@gmail.com/ telp: +62 89506773834 \\ ${ }^{2}$ Fakultas Ekonomi dan Bisnis Universitas Udayana (Unud), Bali, Indonesia
}

\begin{abstract}
ABSTRAK
Penelitian ini bertujuan untuk mengetahui pengaruh teknologi informasi, partisipasi manajemen, kemampuan pemakai SIA, pendidikan dan pelatihan pada kinerja manajemen LPD. Penelitian ini dilakukan pada 35 Lembaga Perkreditan Desa (LPD) di Denpasar. Sampel yang digunakan dalam penelitian ini berjumlah 35 LPD di Denpasar, dengan total sampel yang digunakan sebanyak 105 responden menggunakan metode purposive sampling sebagai metode penentuan sampelnya. Metode pengumpulan data dalam penelitian ini dilakukan dengan menggunakan kuesioner. Teknik analisis data yang digunakan adalah regresi linear berganda. Berdasarkan hasil analisis ditemukan bahwa teknologi, partisipasi manajemen, kemampuan pemakai SIA, pendidikan dan pelatihan berpengaruh positif pada kinerja manajemen LPD di Denpasar.
\end{abstract}

Kata kunci: teknologi informasi, partisipasi manajemen, kemampuan pemakai SIA, pendidikan dan pelatihan, kinerja manajemen LPD

\begin{abstract}
This study aims to determine the effect of information technology, participation on management, user capabilities SIA, educationan and training of management performance LPD. This research was conducted at 35 LPD in Denpasar. The sample used in this study amounted to 35 LPD so that the total sample used amounted to 105 respondents by using purposive sampling method as the method of determining the sample. Data collection method used in this research using questionnaires. Data analysis technique used is multiple linear regression. Based on the analysis result, it is found that information technology, the participation on management, user capabilities SIA, educationan and training have positive effect on LPD management performance in Denpasar. Keywords: information technology, participation on management, user capabilities SIA, educationan and training, management performance LPD
\end{abstract}




\section{PENDAHULUAN}

Teknologi dapat membantu manusia dalam berhubungan dengan pihak lain tidak dibatasi oleh waktu dan tempat dalam memperloleh informasi dan menyebarkan informasi kepada orang lain. Kao et.,al (1996) menyatakan bahwa teknologi lebih bermanfaat ketika di dukung oleh sistem manajemen yang baik dan teknologi memiliki batas kontribusi terhadap produktivitas. Palamountain (2012) suatu organisasi harus memiliki teknologi yang cukup untuk memudahkan tugas manajemen sehingga meningkatkan produktivitas kinerja manajemen. Partisipasi manajemen sangat berperan penting, karena para manajer dapat memastikan bahwa teknologi yang digunakan dapat dimanfaatkan untuk bisnis (Pfano \& Beharry, 2016).

Raymond dan Pare (1992), partisipasi manajemen berhubungan dengan perencana, pengendalikan, koordinasi, evaluasi terhadap teknologi yang digunakan dalam suatu organisasi, dan memimpin karyawan di dalam organisasi Nopalia (2012), menyatakan partisipasi manajemen berpengaruh terhadap pertumbuhan pengembangan organisasi, dimana manajemen dapat mengambil keputusan lebih baik untuk pencapaian tujuan perusahaan secara maksimal, diperlukan juga informasi akuntansi manajemen sebagai pedoman bagi manajemen. Selain partisipasi manajemen, pemakai sistem informasi berperan penting dalam kemajuan suatu perusahaan.

Kemampuan pemakai sistem yang handal sangat diharapkan, dimana kemampuan pemakai akan menunjukkan sejauh mana pengguna menguasai sistem akuntansi yang dikembangkan sehingga dapat meningkatkan kinerja sistem 
informasi akuntansi. (Satya Wirawan, Bima dan Sadha Suardikha, 2016) Sistem Informasi Akuntansi (SIA) di suatu organisasi akan lebih efektif jika para pengguna sistem mampu dalam menjalankan sistem informasi akuntansi dan sarana yang disediakan bagi pengguna, sehingga akan membantu individu dalam menyelesaikan tugas, seperti pada saat mengakses data, sehingga dapat meningkatkan kinerja suatu organisasi. Kemampuan pemakai perlu ditingkatkan dengan mengadakan program pendidikan dan pelatihan, agar pengguna sistem lebih terampil dalam menjalankan sistem informasi akuntansi tersebut. Program pendidikan dan pelatihan akan memberikan keuntungan pada perusahaan dan pengguna sistem dalam menjalankan kegiatan operasional suatu organisasi (Adisanjaya, Wahyuni, dan Puranmawati, 2017). Pentingnya diadakan program pendidikan dan pelatihan ini untuk menambah wawasan serta kemampuan karyawan dalam menyelesaikan tugasnya.

Kinerja manajemen merupakan kinerja para individu dalam kegiatankegiatan manajerial, seperti: perencanaan, investigasi, koordinasi, evaluasi, pengawasan, pengaturan staf, negosiasi, dan perwakilan (Mahoney, 1963). Kinerja yang tinggi dapat menyebabkan meningkatnya kualitas, efisiensi, dan efektivitas, sehingga menjadi lebih mudah dalam menyelesaikan pekerjaan yang ditugaskan ke setiap individu (Murty dan Hudiwinarsih, 2012).

Sistem informasi sangat penting untuk menunjang kelancaran kinerja suatu organisasi, seperti salah satunya pada Lembaga Perkreditan Desa (LPD). LPD adalah lembaga keuangan milik desa adat di Bali yang bertempat di wilayah desa adat itu sendiri. Sebagai lembaga milik desa adat hasil pengelolaannya juga dapat 
Ni Komang Diana Pradasari dan Ida Bagus Dharmadiaksa. Pengaruh.....

dinikmati oleh masyarakat desa setempat. Banyaknya lembaga keuangan lainnya akan meningkatkan persaingan antara LPD dengan lembaga keuangan yang ada, sehingga LPD dituntut untuk terus meningkatkan pelayanannya. LPD di Denpasar telah memanfaatkan teknologi informasi, seperti salah satunya adalah dengan menggunakan Sistem informasi berbasis komputer atau Computer Based Information System (CBIS). Sistem yang sedang di kembangkan LPD saat ini yaitu program yang bernama Intergrated Micro Banking System atau dikenal dengan IBS. Masalah yang sering dialami oleh LPD yang menerapkan program ini adalah sarana prasaran yang masih kurang, jaringan internet yang sering mengalami gangguan, dan beberapa karyawan yang masih belum bisa menerima adanya sistem baru yang berbasis online. Alasan karyawan menolak sistem yang baru karena karyawan masih takut menggunakan sistem tersebut karena sudah terbiasa menggunakan yang lama, yaitu dengan Ms. Excel. Salah satu kelemahan dari Ms. Excel yaitu data yang dihasilkan kurang akurat karena dapat dimanipulasi. Masalah yang juga dialami beberapa LPD adalah Ketika teknologi yang diterapkan dalam sistem informasi tidak dimanfaatkan secara maksimal oleh pemakai sistem, ini dikarenakan beberapa karyawan masih belum percaya terhadap penggunaan teknologi. penerapan teknologi informasi belum bisa mengurangi penggunaan kertas dan belum dilaksanakan secara efektif dan efisien.

Hasil penelitian mengenai kinerja yang dilakukan oleh (Pfano \& Beharry, 2016) mendapatkan hasil bahwa manfaat teknologi berpengaruh positif kinerja manajemen di Durban Westville. (Chintya, 2015) Pemanfaatan Teknologi Informasi memiliki pengaruh positif terhadap Kinerja Instansi Pemerintah. 
Berbeda dengan hasil penelitian yang dilakukan oleh Nasir dan Ranti (2013) Pemanfaatan Teknologi Informasi tidak berpengaruh terhadap Kinerja Instansi Pemerintah. (Kashani \& Shahsavarani, 2015) partisipasi manajemen berpengaruh positif signifikan pada kinerja perusahaan di Tehran Regional Water Company's Staff Iran. (Mulyana, Christina, dan Brahmana, 2017) kompetensi sumber daya manusia berpengaruh positif pada kinerja manajerial di Universitas Widyatama. (Khan, Khan, \& Khan, 2011) pendidikan dan pelatihan berpengaruh positif pada kinerja organisasi Islamabad di Pakistan.

Penelitian ini mengambil obyek pada LPD di Denpasar, karena perkembangan LPD cukup pesat jika dilihat dari aset yang dimiliki LPD di Denpasar, ini menandakan bahwa kepercayaan masyarakat terhadap LPD sudah meningkat, sehingga perlu diteliti bagaimana pengaruh teknologi informasi, partisipasi manajemen, kemampuan pemakai, pendidikan dan pelatihan pada kinerja LPD. Tabel 1 menunjukan perkembanngan LPD di Denpasar.

Tabel 1.

Perkembangan LPD di Denpasar

\begin{tabular}{ccc}
\hline \multicolumn{1}{c}{ Tahun } & Aset & Jumlah Karyawan \\
\hline 2014 & Rp 1.179.967.305 & 485 orang \\
2015 & Rp 1.383.896.375 & 508 orang \\
2016 & Rp 1.625.610.986 & 525 orang \\
\hline $\begin{array}{l}\text { Persentase kenaikan } \\
\text { 2014-2015 }\end{array}$ & 17,28 & 4,74 \\
Persentase kenaikan & 17,46 & 3,34 \\
2015-2016 & & \\
\hline Sumber: LP LPD Kota Denpasar, 2017 & \\
\hline
\end{tabular}


Ni Komang Diana Pradasari dan Ida Bagus Dharmadiaksa. Pengaruh.....

Tabel 1 menjelaskan jumlah aset dari tahun 2014-2015 terjadi peningkatan sebesar Rp 203.929.070 atau 17,28\% dan tahun 2015-2016 meningkat sebesar Rp 241.714.611 atau 17,46\%. Perkembangan aset LPD di Denpasar kenaikan jumlah aset dari tahun 2014-2016, seperti dalam tabel tersebut menjelaskan bahwa meningkatnya volume transaksi yang dapat dilihat dari jumlah rupiahnya. Peningkatan tersebut tentu karena kepercayaan masyarakat terhadap LPD sudah meningkat. Oleh karena itu, dibutuhkan pengolahan data yang lebih praktis. Pengolahan data yang lebih praktis dapat dicapai melalui penerapan sistem informasi akuntansi yang memanfaatkan teknologi.

Berdasarkan paparan di atas maka rumusan masalah dalam penelitian ini adalah: 1) Apakah teknologi informasi berpengaruh pada kinerja manajemen LPD di Denpasar?; 2) Apakah partisipasi manajemen berpengaruh pada kinerja manajemen LPD di Denpasar?; 3) Apakah kemampuan pemakai SIA berpengaruh pada kinerja manajemen LPD di Denpasar?; 4) Apakah pendidikan dan pelatihan berpengaruh pada kinerja manajemen LPD di Denpasar?.

Mengacu pada pokok permasalahan tersebut, maka tujuan dalam penelitian ini adalah: 1) Untuk mengetahui secara empiris pengaruh teknologi informasi pada kinerja manajemen LPD di Denpasar; 2) Untuk mengetahui secara empiris pengaruh partisipasi manajemen pada kinerja manajemen LPD di Denpasar; 3) Untuk mengetahui secara empiris pengaruh kemampuan pemakai SIA pada kinerja manajemen LPD di Denpasar; 4) Untuk mengetahui secara empiris pengaruh pendidikan dan pelatihan pada kinerja manajemen LPD di Denpasar. 
Penelitian ini diharapkan dapat memberikan kegunaan secara teoritis maupun secara praktis. Secara teoritis, Penelitian ini dapat menambah pengetahuan dan wawasan dalam menerapkan teori yang telah di pelajari dengan fakta yang ada dan dalam rangka mengembangkan ilmu pengetahuan dunia pendidikan terutama mengenai bagaimana pengaruh Teknologi Informasi, Partisipasi Manajemen, Kemampuan Pemakai SIA, Pendidikan dan Pelatihan Pada Kinerja Manajemen LPD di Denpasar. Secara praktis, Penelitian ini dapat meemberikan informasi dan menjadi bahan refrensi bagi pihak-pihak yang berkepentingan dalam pengambilan kebijakan yang berkaitan dengan Kinerja Manajemen LPD.

Technology Acceptance Model (TAM) adalah teori yang mempelajari mengenai sikap individu untuk menerima dan menggunakan teknologi yang didasarkan pada persepsi kebermnfaatan (Perceived Usefulness) dan kemudahan penggunaan (Perceived Ease of Use). Sistem informasi akan digunakan dengan baik apabila sistem tersebut mudah digunakan oleh pengguna serta menghasilkan manfaat dan menguntungkan dalam peningkatan kinerjanya (Davis, 1989).

Ozera \& Yilmaz (2011) menyatakan bahwa sebuah organisasi dalam menyelaraskan faktor lingkungan internal maupun faktor lingkungan eksternal tidak memiliki metode terbaik untuk dapat mencapai terbaik yang mempengaruhi hubungan antara sistem pengendalian degan kinerja. Fisher (1998) beberapa variabel kontingensi yang dapat terjadi dalam suatu sistem pengendalian manajemen sebuah perusahaan dapat dibagi ke dalam lima kategori yaitu, ketidakpastian (uncertainty), teknologi \& interdependensi perusahaan, variabel 
yang terkait dengan dengan industri, perusahaan, dan unit bisnis, misi \& strategi kompetitif, dan faktor-faktor yang dapat diobservasi (observability).

Manajemen sumber daya manusia atau dikenal dengan Human Resaource Management (HRM) adalah teori yang mempelajari mengenai aspek manusia atau sumber daya manusia khususnya pihak manajemen yaitu terlibat dalam proses melatih, menilai, memperoleh dan memberikan kompensasi kepada karyawan, memperhatikan hubungan kerja, kesehatan, keamanan dan masalah keadilan (Dessler 2006:5).

Ikhsan dan Teddy $(2008 ; 25)$ teknologi informasi adalah suatu alat untuk memudahkan pekerjaan manusia dalam penggunaan komputer dan teknologi yang berhubungan dengan sumber informasi. Penerapan teknologi informasiagar efektif dapat dilakukan dengan cara meningkatkan kinerja pemakainya, namun tidak berarti setiap individu menerima secara positif keberadaan teknologi tersebut dan dapat merasakan manfaatnya (Thompson, Higgins, \& Howell, 1991). (Ismail \& King, 2007), menyatakan perusahaan yang menggunakan teknologi yang modern memiliki sistem informasi yang baik dibandingkan dengan perusahaan yang tidak menggunakan teknologi. Pemanfaatan teknologi informasi memiliki dampak positif yang secara umum adalah terjadi efisiensi waktu dan biaya yang secara jangka panjang akan memberikan keuntungan ekonomis yang sangat tinggi, jika teknologi informasi yang ada mampu dimanfaatkan secara optimal maka akan memberikan pengaruh positif terhadap kinerja instansi pemerintah (Chintya, 2015). Hasil penelitian yang dilakukan oleh (Pfano \& Beharry, 2016) manfaat 
teknologi berpengaruh positif terhadap kinerja manajemen di Durban Westville Berdasarkan uraian tersebut maka dirumuskan hipotesis sebagai berikut:

H1: Teknologi informasi berpengaruh positif pada kinerja manajemen LPD

Partisipasi manajemen berpengaruh terhadap kinerja manajemen dalam pertumbuhan pengembangan organisasi. Manajemen dapat mengambil keputusan lebih baik untuk pencapaian tujuan perusahaan secara maksimal, sehingga diperlukan informasi akuntansi manajemen sebagai pedoman bagi manajemen (Nopalia., 2012). Manajemen memiliki tugas membandingkan informasi kinerja sebelumnya untuk mengukur sejauh mana tujuan dan sasaran yang dicapai organisasi dengan melihat hasil dan kondisi yang terjadi saat ini (Soudani, 2012). Partisipasi manajemen berpengaruh positif signifikan pada kinerja perusahaan di Tehran Regional Water Company's Staff Iran (Kashani \& Shahsavarani, 2015). Berdasarkan uraian tersebut maka dirumuskan hipotesis sebagai berikut:

$\mathrm{H}_{2}$ : Partisipasi manajemen berpengaruh positif pada kinerja manajemen LPD.

Sistem informasi akuntansi merupakan suatu keunggulan yang dimiliki oleh perusahaan yang merupakan variabel paling memengaruhi kinerja keuangan (Soudani, 2012). Suatu organisasi dalam menjalankan sistem informasi akan memberikan manfaat jika sistem tersebut digunakan secara efektif yang didukung oleh kemampuan pemakai SIA serta sarana yang disediakan bagi pengguna, sehingga membantu pemakai dalam mengakses data yang diperlukan dalam menyelesaikan tugas individu di suatu perusahaan atau organisasi (Satya Wirawan, Bima dan Sadha Suardikha, 2016). Kompetensi sumber daya manusia berpengaruh positif pada kinerja manajerial di Universitas Widyatama (Mulyana, 
Ni Komang Diana Pradasari dan Ida Bagus Dharmadiaksa. Pengaruh.....

Christina, dan Brahmana, 2017). Berdasarkan uraian diatas maka dapat dirumuskan hipotesis sebagai berikut:

$\mathrm{H}_{3}$ : Kemampuan pemakai SIA berpengaruh positif pada kinerja manajemen LPD

Sistem informasi akuntansi yang efektif juga harus diimbangi dengan program pelatihan dan pendidikan, hal ini perlu diadakan untuk karyawan dalam menjalankan sistem informasi akuntansi yang terkomputerisasi tersebut agar karyawan lebih terampil dalam menggunakan sistem yang ada, sehingga program pelatihan dan pendidikan tersebut akan memberikan keuntungan pada perusahaan dan pengguna sistem dalam menjalankan kegiatan operasional perusahaan (Adisanjaya, Wahyuni, dan Purnamawati, 2017). Pendidikan dan pelatihan berpengaruh positif pada kinerja organisasi Islamabad di Pakistan (Khan et al., 2011). Berdasarkan uraian diatas maka dapat dirumuskan hipotesis sebagai berikut:

$\mathrm{H}_{4}$ : Pendidikan dan pelatihan berpengaruh positif pada kinerja manajemen LPD

\section{METODE PENELITIAN}

Desain penelitian yang digunakan dalam penelitian ini merupakan penelitian kuantitatif yang berbentuk asosiatif, dimana penelitian ini bertujuan untuk mengetahui hubungan antara dua variabel atau lebih (Sugiyono, 2016:13). Penelitian ini dilakukan pada LPD Kota Denpasar, lokasi ini dipilih karena LPD di Denpasar sudah mulai menerapkan SIA berbasis online serta aset yang dimiliki LPD Kota Denpasar terus meningkat setiap tahunnya, ini menandakan bahwa masyarakan di Denpasar sudah mulai mempercayakan LPD sebagai lembaga keuangannya. Obyek dalam penelitian ini adalah teknologi informasi, partisipasi 
manajemen, kemampuan pemakai, pendidikan dan pelatihan pada Kinerja Manajemen LPD di Denpasar. Variabel terikat dalam penelitian ini adalah kinerja manajemen LPD, sedangkan variabel bebasnnya teknologi informasi, partisipasi manajemen, kemampuan pemakai SIA, pendidikan dan pelatihan.

Kinerja manajemen merupakan berbagai kegiatan untuk mencapai tujuan perusahaan, karena setiap kegiatan tersebut memerlukan sumber daya, maka kinerja manajemen akan tercermin dari penggunaan sumber daya untuk mencapai tujuan perusahaan (Meriewaty, D \& Setyani, 2005). Variabel kinerja manajemen organisasi ini secara operasional diukur dengan menggunakan 4 (empat) indikator yang diadopsi dari Brahmasari (2004), yaitu: (1) Kemampuan dalam meningkatkan efektivitas dan efisiensi penggunaan sumber daya manusia yang dimiliki, (2) Kemampuan dalam meningkatkan efisiensi penggunaan seluruh waktu yang dimiliki, (3) Kemampuan dalam beradaptasi terhadap perubahan, (4) Kemampuan dalam mencapai target yang telah ditetapkan. Pernyataan diukur dengan menggunakan skala likert 4 poin, yaitu: sangat tidak setuju di beri skor 1 , tidak setuju di beri skor 2, setuju diberi skor 3, sangat setuju diberi skor 4 .

Menurut Ikhsan dan Teddy (2008;25), teknologi informasi adalah suatu alat untuk memudahkan pekerjaan manusia dalam penggunaan komputer dan teknologi yang berhubungan dengan sumber informasi. Menurut Astuti terdapat 6 faktor yang memengaruhi pemanfaatan teknologi informasi yaitu sosial, affect, kompleksitas, kesesuaian tugas, konsekuensi jangka panjang dan kondisi yang memfasilitasi. Pernyataan diukur dengan menggunakan skala likert 4 poin, yaitu: 
Ni Komang Diana Pradasari dan Ida Bagus Dharmadiaksa. Pengaruh.....

sangat tidak setuju di beri skor 1, tidak setuju di beri skor 2, setuju diberi skor 3, sangat setuju diberi skor 4 .

Mooney (2008) Partisipasi manajemen adalah keikutsertaan manajemen menjalankan sistem informasi akuntansi dan membuat strategi pengembangan untuk sistem informasi yang akan diimplementasikan. Irma (2014) mengukur variabel partisipasi manajemen menggunakan 6 indikator yaitu: 1). perangkat lunak yang disediakan, 2). tenaga dan peralatan, 3). Pengadaan pelatihan, 4). Aktif terlibat dalam pengembangan sistem, 5). Memiliki harapan yang tinggi terhadap penggunaan sistem, 6). Evaluasi sistem dari penggunaan sistem. Pernyataan diukur dengan skala likert 4 poin yaitu angka 1 menunjukkan sangat tidak setuju, angka 2 menunjukkan tidak setuju, angka 3 menunjukkan setuju dan angka 4 menunjukkan sangat setuju.

Robbins (2008) kemampuan adalah kapasitas seorang individu melakukan berbagai tugas dalam sebuah pekerjaan. Kemampuan bisa diartikan sebagai kecakapan, ketangkasan, kesanggupan untuk melakukan suatu perbuatan atau pekerjaan (Satya Wirawan, Bima dan Sadha Suardikha, 2016). Kemampuan pemakai sistem dinilai berdasarkan 3 indikator dan 3 pernyataan dengan menggunakan instrument yang dikembangkan oleh Almilia dan Briliantien (2007), yaitu: 1). Pengetahuan , 2). Kemampuan, 3). Keahlian. Pernyataan diukur dengan skala likert 4 poin yaitu angka 1 menunjukkan sangat tidak setuju, angka 2 menunjukkan tidak setuju, angka 3 menunjukkan setuju dan angka 4 menunjukkan sangat setuju. 
Pendidikan dan peltihan adalah suatu proses pembelajaran baik secara teoritis maupun secara praktis yang bertujuan untuk peningkatan keterampilan dan pengetahuan individu dari tidak tahu menjadi tahu (Wilayanti, 2016). Variabel ini menggunakan instrument yang dikembangan oleh Almilia dan Briliantien (2007) dengan skala likert 4 poin dengan 4 pernyataan yaitu sangat tidak setuju diberi skor 1, tidak setuju diberi skor 2, setuju diberi skor 3, sangat setuju diberi skor 4 .

Populasi dalam penelitian ini adalah LPD di Denpasar sebanyak 35 LPD. Metode pengumpulan sampel yang digunakan dalam penelitian ini adalah non probability sampling yaitu dengan metode purposive sampling. Purposive sampling adalah teknis pengambilan sampel yang dilakukan dengan kriteria yang telah dikehendaki. Kriteria pemilihan sampel dalam penelitian ini yaitu: 1). Individu yang menjabat sebagai pengurus LPD di Denpasar, 2). Pengurus LPD yang bekerja lebih dari satu tahun, 3). Pernah mengikuti pendidikan dan pelatihan. Jadi jumlah sampel yang digunakan adalah sebanyak 105 responden, dengan menggunakan metode kuesioner dalam pengumpulan data. Kuesioner merupakan teknik pengumpulan data yang dilakukan dengan cara memberikan seperangkat pertanyaan atau pernyataan tertulis kepada responden untuk dijawab (Sugiyono, 2016:137).

Teknik analisis data yang digunakan dalam penelitian ini adalah regresi linear berganda dirumuskan sebagai berikut:

$Y=\alpha+\beta_{1} X_{1}+\beta_{2} X_{2}+\beta_{3} X_{3}+\beta_{4} X_{4}+e$ 
Ni Komang Diana Pradasari dan Ida Bagus Dharmadiaksa. Pengaruh.....

Keterangan:

\begin{tabular}{|c|c|}
\hline Y & $=$ Kinerja Manajemen LPD \\
\hline$\alpha$ & $=$ Bilangan Konstanta \\
\hline$\beta_{1,2,3,4}$ & $=$ Koefisien Regresi dari variabel independen \\
\hline $\mathrm{X}_{1}$ & $=$ Teknologi Informasi \\
\hline $\mathrm{X}_{2}$ & $=$ Partisipasi Manajemen \\
\hline $\mathrm{X}_{3}$ & $=$ Kemampuan Pemakai SIA \\
\hline $\mathrm{X}_{4}$ & $=$ Pendidikan dan Pelatihan \\
\hline & $=$ Error \\
\hline
\end{tabular}

Data penelitian ini dikumpulkan melalui penyebaran kuesioner dengan sampel yaitu 105 responden. Kuesioner yang disebarkan ke responden sebanyak 105 kuesioner. Semua kuesioner yang disebarkan kembali dan semua dapat digunakan yaitu sebanyak 105 kuesioner.

Statistik deskriptif digunakan untuk mendeskripsikan variabel-variabel yang digunakan dalam penelitian ini. Hasil uji statistik deskriptif dalam penelitian ini dapat dilihat pada Tabel 2 berikut.

Tabel 2.

Statistik Deskriptif

\begin{tabular}{llllll}
\hline Variabel & N & Min. & Max. & Mean & $\begin{array}{l}\text { Std. } \\
\text { Deviasi }\end{array}$ \\
\hline Teknologi Informasi $\left(\mathrm{X}_{1}\right)$ & 105 & 15 & 24 & 21,10 & 2,148 \\
Partisipasi Manajemen $\left(\mathrm{X}_{2}\right)$ & 105 & 16 & 24 & 20,67 & 2,348 \\
Kemampuan Pemakai SIA $\left(\mathrm{X}_{3}\right)$ & 105 & 9 & 12 & 10,82 & 1,158 \\
Pendidikan dan Pelatihan $\left(\mathrm{X}_{4}\right)$ & 105 & 11 & 16 & 14,41 & 1,479 \\
Kinerja Manajemen LPD $(\mathrm{Y})$ & 105 & 11 & 16 & 13,68 & 1,458 \\
\hline Sumber: Data diolah, 2017 & & & & &
\end{tabular}

Pada Tabel 2 dapat dilihat hasil statistik masing-masing variabel, yang selanjutnya dapat diuraikan deskripsi dari masing-masing variabel bahwa nilai minimum variabel teknologi informasi (X1) memiliki sebesar 15 , nilai maksimum sebesar 24, mean sebesar 21,10 dan standar deviasi sebesar 2,148. Nilai rata-rata sebesar 21,10, dimana secara rata-rata jawaban dari responden mengarah ke nilai tertinggi dalam menjawab pernyataan kuesioner, ini berarti responden cenderung 
memilih setuju pada masing-masing item pernyataan yang artinya penggunaan teknologi informasi cukup tinggi. Standar deviasi pada variabel teknologi informasi sebesar 2,148. Hal ini menunjukkan bahwa standar penyimpangan data terhadap nilai rata-rata adalah 2,148 .

Partisipasi manajemen (X2) memiliki nilai minimum sebesar 16, nilai maksimum 24, mean sebesar 20,67, dan standar deviasi sebesar 2,348. Nilai rataratanya sebesar 20,67, dimana secara rata-rata jawaban responden mengarah ke nilai tertinggi dalam menjawab pernyataan kuesioner, ini berarti responden cenderung memilih setuju pada masing-masing item pernyataan yang artinya tingkat partisipasi manajemen cukup tinggi. Standar deviasi pada variabel partisipasi manajemen sebesar 2,348. Hal ini menunjukkan bahwa standar penyimpangan data terhadap nilai rata-rata adalah 2,348 .

Kemampuan pemakai SIA (X3), memiliki nilai minimum sebesar 9, nilai maksimum sebesar 12 , mean sebesar 10,82 , dan standar deviasi 1,158 . Nilai rataratanya sebesar 10,82, dimana secara rata-rata jawaban responden mengarah ke nilai tertinggi dalam menjawab pernyataan kuesioner, ini berarti responden cenderung memilih setuju pada masing-masing item pernyataan yang artinya tingkat kemampuan pemakai SIA cukup tinggi. Standar deviasi pada variabel kemampuan pemakai SIA sebesar 1,158. Hal ini menunjukkan bahwa standar penyimpangan data terhadap nilai rata-rata adalah sebesar 1,158 .

Pendidikan dan pelatihan (X4), memiliki nilai minimum sebesar 11, nilai maksimum sebesar 16, mean sebesar 14,41, dan standar deviasi 1,479. Nilai rataratanya sebesar 14,41 menunjukkan secara rata-rata jawaban responden mengarah 
Ni Komang Diana Pradasari dan Ida Bagus Dharmadiaksa. Pengaruh.....

ke nilai tertinggi dalam menjawab pernyataan kuesioner, ini berarti responden cenderung memilih setuju pada masing-masing item pernyataan yang artinya tingkat pendidikan dan pelatihan cukup tinggi. Standar deviasi pada variabel pendidikan dan pelatihan sebesar 1,479. Hal ini menunjukkan bahwa standar penyimpangan data terhadap nilai rata-rata adalah sebesar 1,479.

Kinerja manajemen LPD (Y), memiliki nilai minimum sebesar 11, nilai maksimum sebesar 16 , mean sebesar 13,68 , dan standar deviasi 1,458. Nilai rataratanya sebesar 13,68 menunjukkan secara rata-rata jawaban responden mengarah ke nilai tertinggi dalam menjawab pernyataan kuesioner, ini berarti responden cenderung memilih setuju pada masing-masing item pernyataan yang artinya tingkat kinerja manajemen cukup tinggi. Standar deviasi pada variabel kinerja manajemen LPD sebesar 1,458. Hal ini menunjukkan bahwa standar penyimpangan data terhadap nilai rata-rata adalah sebesar 1,458 .

Uji asumsi klasik dilakukan sebelum dianalisis regresi berganda. Uji asumsi klasik yang pertama adalah uji normalitas. Uji normalitas bertujuan untuk menguji apakah dalam residual dari model regresi yang dibuat berdistribusi normal atau tidak. Hasil dari uji normalitas dapat dilihat pada Tabel 3.

Tabel 3.

Hasil Uji Normalitas

\begin{tabular}{lllll}
\hline No. & Persamaan & N & Kolmogarav Smirnov Z & $\begin{array}{c}\text { Asymp. Sig (2- } \\
\text { tailed) }\end{array}$ \\
\hline $1 \quad \begin{array}{l}\mathrm{Y}=\alpha+\beta_{1} \mathrm{X}_{1}+\beta_{2} \mathrm{X}_{2}+\beta_{3} \mathrm{X}_{3}+ \\
\beta_{4} \mathrm{X}_{4}+e\end{array}$ & 105 & 1,121 & 0,162 \\
\hline
\end{tabular}

Sumber: Data diolah, 2017 
Berdasarkan Tabel 3 di atas dapat dilihat nilai signifikansi untuk persamaan model penelitian ini adalah sebesar 0,162>0,05. Hal ini menunjukkan bahwa, model regresi pada penelitian ini berdistribusi normal.

Uji asumsi klasik yang kedua adalah uji multikolinieritas yang memiliki tujuan untuk melakukan pengujian pada model regresi apakah ditemukan adanya korelasi antar variabel bebas. Hasil dari uji multikolinieritas ditampilkan pada Tabel 4.

Tabel 4.

Hasil Uji Multikolinearitas

\begin{tabular}{lcc}
\hline \multicolumn{1}{c}{ Variabel } & \multicolumn{2}{c}{ Colinearity Statistic } \\
& Tolerance & VIF \\
\hline Teknologi Informasi $\left(\mathrm{X}_{1}\right)$ & 0,916 & 1,092 \\
Partisipasi Manajemen $\left(\mathrm{X}_{2}\right)$ & 0,935 & 1,069 \\
Kemampuan Pemakai SIA $\left(\mathrm{X}_{3}\right)$ & 0,971 & 1,030 \\
Pendidikan dan Pelatihan $\left(\mathrm{X}_{4}\right)$ & 0,991 & 1,009 \\
\hline Sumber: Data diolah, 2017 & &
\end{tabular}

Berdasarkan Tabel 4 nilai tolerance pada masing-masing variabel lebih dari $10 \%(0,1)$, dan nilai VIF masing-masing variabel yang lebih kecil dari 10 . Hal ini berarti model regresi bebas dari masalah multikolinearitas.

Uji asumsi klasik yang ketiga yaitu uji heteroskedastisitas yang digunakan unttuk menguji model regresi dalam penelitian ini apakah terjadi ketidaksamaan varians dari residual satu pengamatan ke pengamatan yang lain. Suatu model regresi dikatakan bebas heteroskedastisitas apabila signifikansi t tiap variabel bebas diatas 0,05. Hasil dari uji heteroskedastisitas bisa dilihat pada Tabel 5 . 
Tabel 5.

Hasil Uji Heteroskedastisitas

\begin{tabular}{|c|c|c|c|c|c|}
\hline \multirow[t]{2}{*}{ Variabel } & \multicolumn{2}{|c|}{$\begin{array}{l}\text { Unstandardized } \\
\text { Coefficients }\end{array}$} & \multirow{2}{*}{$\begin{array}{c}\text { Standardized } \\
\text { Coefficients } \\
\text { Beta } \\
\end{array}$} & \multirow[t]{2}{*}{$\mathbf{t}$} & \multirow[t]{2}{*}{ Sig. } \\
\hline & B & Std. Error & & & \\
\hline (Constant) & 0,171 & 1,196 & & 0,143 & 0,886 \\
\hline Teknologi Informasi $\left(\mathrm{X}_{1}\right)$ & 0,026 & 0,034 & 0,079 & 0,765 & 0,446 \\
\hline Partisipasi Manajemen $\left(\mathrm{X}_{2}\right)$ & 0,022 & 0,031 & 0,071 & 10,699 & 0,486 \\
\hline Kemampuan Pemakai SIA $\left(\mathrm{X}_{3}\right)$ & 0,049 & 0,061 & 0,080 & 0,798 & 0,427 \\
\hline Pendidikan dan Pelatihan $\left(\mathrm{X}_{4}\right)$ & 0,032 & 0,048 & 0,068 & 0,681 & 0,497 \\
\hline
\end{tabular}

Sumber: Data diolah, 2017

Berdasarkan Tabel 5 menunjukan bahwa signifikansi t tiap variabel bebas diatas 0,05 , sehingga dapat disimpulkan model regresi penelitian ini tidak terdapat gejala heteroskedastisitas.

Berdasarkan hasil olah data dengan bantuan SPSS, maka didapatkan hasil analisis regresi linear berganda seperti pada Tabel 6 berikut.

Tabel 6.

Hasil Regresi Linear Berganda

\begin{tabular}{|c|c|c|c|c|c|}
\hline \multirow[t]{2}{*}{ Variabel } & \multicolumn{2}{|c|}{$\begin{array}{l}\text { Unstandardized } \\
\text { Coefficients }\end{array}$} & \multirow{2}{*}{$\begin{array}{l}\text { Stardardized } \\
\text { Coefficients } \\
\text { Beta }\end{array}$} & \multirow[t]{2}{*}{$\mathbf{T}$} & \multirow[t]{2}{*}{ Sig. } \\
\hline & B & Std. Error & & & \\
\hline (Constant) & 7,542 & 2,247 & & 3.356 & 0,001 \\
\hline Teknologi Informasi $\left(\mathrm{X}_{1}\right)$ & 0,131 & 0,064 & 0,193 & 2,047 & 0,043 \\
\hline Partisipasi Manajemen $\left(\mathrm{X}_{2}\right)$ & 0,116 & 0,058 & 0,187 & 2,001 & 0,048 \\
\hline Kemampuan Pemakai SIA $\left(\mathrm{X}_{3}\right)$ & 0,245 & 0,116 & 0,195 & 2,121 & 0,036 \\
\hline Pendidikan dan Pelatihan $\left(\mathrm{X}_{4}\right)$ & 0,251 & 0,090 & 0,254 & 2,800 & 0,006 \\
\hline$R$ Square & 0,182 & & & & \\
\hline F hitung & 5,559 & & & & \\
\hline Sig. F & 0,000 & & & & \\
\hline
\end{tabular}

Berdasarkan Tabel 6. dapat disusun permasaan regresi sebagai berikut.

$$
\begin{aligned}
Y & =\alpha+\beta_{1} X_{1}+\beta_{2} X_{2}+\beta_{3} X_{3}+\beta_{4} X_{4}+e \ldots \ldots \ldots \ldots \ldots \\
& =7,542+0,131 X_{1}+0,116 X_{2}+0,245 X_{3}+0,251 X_{4}+e
\end{aligned}
$$

Berdasarkan persamaan diatas, dapat dijelaskan hal-hal sebagai berikut.

Nilai konstanta sebesar 7,542 menjelaskan jika nilai teknologi informasi $\left(\mathrm{X}_{1}\right)$, 
partisipasi manajemen $\left(\mathrm{X}_{2}\right)$, kemampuan pemakai SIA $\left(\mathrm{X}_{3}\right)$, pendidikan dan pelatihan $\left(\mathrm{X}_{4}\right)$, maka nilai kinerja manajemen LPD (Y) sebesar 7,542

Nilai koefisien $\beta_{1}$ sebesar 0,131 . Nilai koefisien bernilai positif menunjukkan bahwa apabila teknologi informasi $\left(\mathrm{X}_{1}\right)$ meningkat, maka kinerja manajemen LPD (Y) akan meningkat dengan asumsi variabel lainnya konstan.

Nilai koefisien $\beta_{2}$ sebesar 0,116 . Nilai koefisien bernilai positif menunjukkan bahwa apabila partisipasi manajemen $\left(\mathrm{X}_{2}\right)$ meningkat, maka kinerja manajemen LPD (Y) akan meningkat dengan asumsi variabel lainnya konstan.

Nilai koefisien $\beta_{3}$ sebesar 0,245 . Nilai koefisien bernilai positif menunjukkan bahwa apabila kemampuan pemakai SIA $\left(\mathrm{X}_{3}\right)$ meningkat, maka kinerja manajemen (Y) akan meningkat dengan asumsi semua variabel lainnya konstan.

Nilai koefisien $\beta_{4}$ sebesar 0,251. Nilai koefisien bernilai positif menunjukkan bahwa apabila pendidikan dan pelatihan $\left(\mathrm{X}_{4}\right)$ meningkat, maka kinerja manajemen LPD (Y) dengan asumsi semua variabel lainnya konstan.

Berdasarkan Tabel 6 menunjukkan bahwa nilai dari Adjusted R Square adalah 0,149 atau 14,9 persen, hal ini berarti sebesar 14,9 persen variasi kinerja manajemen LPD dipengaruhi oleh model yang di bentuk oleh teknologi informasi $\left(\mathrm{X}_{1}\right)$, partisipasi manajemen $\left(\mathrm{X}_{2}\right)$, kemampuan pemakai SIA $\left(\mathrm{X}_{3}\right)$, pendidikan dan pelatihan $\left(\mathrm{X}_{4}\right)$, sedangkan sisanya ditentukan oleh faktor lain sebesar persen 85,1 persen.

Uji kelayakan model (uji F) menunjukkan bahwa nilai $\mathrm{F}$ hitung yang diperoleh adalah sebesar 5,559 dengan nilai signifikansi sebesar 0,000 yang lebih 
kecil dari nilai $a=0,05$, ini berarti, seluruh variabel bebas (teknologi informasi, partisipasi manajemen, kemampuan pemakai SIA, pendidikan dan pelatihan) dapat memprediksi atau menjelaskan mengenai kinerja manajemen LPD di Kota Denpasar.

Tabel 6 menunjukkan nilai koefisien variabel teknologi informasi sebesar 2,047 dengan nilai signifikansi sebesar 0,043. Nilai ini lebih kecil dari $a$ yaitu 0,05, maka $\mathrm{H}_{0}$ ditolak $\mathrm{H}_{1}$ diterima, sehingga dapat disimpulkan teknologi informasi berpengaruh positif pada kinerja manajemen LPD. Hasil penelitian ini sejalan dengan hasil penelitian yang dilakukan oleh (Pfano \& Beharry, 2016) manfaat teknologi berpengaruh positif terhadap kinerja manajemen di Durban Westville.

Variabel partisipasi manajemen memiliki nilai koefisien sebesar 2,001 dengan nilai signifikansi sebesar 0,048. Nilai ini lebih kecil dari a yaitu 0,05, maka $\mathrm{H}_{0}$ ditolak $\mathrm{H}_{2}$ diterima, sehingga partisipasi manajemen berpengaruh positif pada kinerja manajemen LPD. Hasil yang di dapat dalam penelitian ini sejalan dengan dengan hasil penelitian yang dilakukan oleh (Kashani \& Shahsavarani, 2015) partisipasi manajemen berpengaruh positif signifikan pada kinerja perusahaan di Tehran Regional Water Company’s Staff Iran.

Variabel kemampuan pemakai SIA memiliki nilai koefisien sebesar 2,121 dengan nilai signifikansi sebesar 0,036. Nilai ini lebih kecil dari a yaitu 0,05, maka $\mathrm{H}_{0}$ ditolak $\mathrm{H}_{3}$ diterima, sehingga kemampuan pemakai SIA berpengaruh positif pada kinerja manajemen LPD. Hasil yang di dapat dalam penelitian ini sejalan dengan dengan hasil penelitian yang dilakukan oleh (Mulyana, Christina 
dan Brahmana, 2017), kompetensi sumber daya manusia berpengaruh positif pada kinerja manajerial di Universitas Widyatama.

Variabel pendidikan dan pelatihan memiliki nilai koefisien sebesar 2,800 dengan nilai signifikansi sebesar 0,006. Nilai ini lebih kecil dari a yaitu 0,05, maka $\mathrm{H}_{0}$ ditolak $\mathrm{H}_{4}$ diterima, sehingga pendidikan dan pelatihan berpengaruh positif pada kinerja manajemen LPD. Hasil yang di dapat dalam penelitian ini sejalan dengan dengan hasil penelitian yang dilakukan oleh (Khan et al., 2011) pendidikan dan pelatihan berpengaruh positif pada kinerja organisasi Islamabad di Pakistan.

Implikasi dari hasil penelitian ini mencakup dua hal, yaitu implikasi teoritis dan praktis. Implikasi secara teoritis yaitu penelitian yang dilakukan diharapkan dapat memberikan kontribusi mengenai pengaruh teknologi informasi, partisipasi manajemen, kemampuan pemakai SIA, pendidikan dan pelatihan pada kinerja manajemen. Penelitian ini dapat membuktikan bahwa semua variabel secara teori mempengaruhi kinerja manajemen LPD.

Implikasi praktisnya yaitu Penelitian ini diaharpkan mampu memberikan kontribusi positif bagi semua pihak khususnya Lembaga Perkreditan Desa (LPD). LPD sebaiknya terus meningkatkan pelayanannya agar mampu bersaing dengan lembaga keuangan lainnya dengan melakukan pengembangan sistem informasi akuntansi dan selalu melakukan evaluasi terhadap sistem informasi yang digunakan serta keterlibatan pihak manajemen terhadap sistem informasi akuntansi yang perlu dikembangkan. 
Ni Komang Diana Pradasari dan Ida Bagus Dharmadiaksa. Pengaruh.....

\section{SIMPULAN}

Berdasarkan hasil analisis pada pembahasan bab-bab sebelumnya dapat disimpulkan sebagai berikut: Teknologi informasi berpengaruh positif pada kinerja manajemen LPD di Denpasar. Hasil penelitian ini memiliki arti bahwa tingkat penggunaan teknologi informasi yang tinggi akan mampu meningkatkan kinerja manajemen LPD di Denpasar, demikian juga sebaliknya, menurunnya tingkat penggunaan teknologi informasi akan menurunkan kinerja manajemen LPD di Denpasar.

Partisipasi manajemen berpengaruh positif pada kinerja manajemen LPD di Denpasar. Hasil penelitian ini memiliki arti tingkat partisipasi manajemen yang tinggi akan mampu meningkatkan kinerja manajemen LPD di Denpasar, demikian juga sebaliknya, menurunnya partisipasi manajemen akan menurunkan kinerja manajemen LPD di Denpasar.

Kemampuan pemakai SIA berpengaruh positif pada kinerja manajemen LPD di Denpasar. Hasil penelitian ini memiliki arti tingkat kemampuan pemakai SIA yang tinggi akan mampu meningkatkan kinerja manajemen LPD di Denpasar, demikian juga sebaliknya, kemampuan yang masih kurang dalam pemakaian SIA pada kinerja manajemen akan menurunkan kinerja manajemen LPD di Denpasar.

Pendidikan dan pelatihan berpengaruh positif pada kinerja manajemen LPD di Denpasar. Hasil penelitian ini memiliki arti tingkat pendidikan dan pelatihan yang tinggi akan mampu meningkatkan kinerja manajemen LPD di Denpasar, demikian juga sebaliknya, menurunnya pengadaan pendidikan dan pelatihan pada kinerja manajemen akan menurunkan kinerja manajemen LPD di Denpasar. 
Berdasarkan simpulan di atas, maka saran yang dapat direkomendasikan adalah sebagai berikut:

Penelitian selanjutnya disarankan menggunakan faktor lain yang dapat memengaruhi kinerja manajemen, seperti komitmen organisasi, etika kerja, motivasi, dan sistem pengendalian intern, karena dalam penelitian ini menghasilkan Adjusted $R$ Square sebesar 14,9 persen yang berarti masih ada 85,1 persen yang disebabkan oleh faktor lain. Penelitian ini mengambil objek LPD di Denpasar, disarankan pada penelitian selanjutnya menggunakan perusahaan lain sebagai sampel penelitian seperti hotel, bank dan wilayah penelitian lain yang cakupannya lebih luas.

\section{REFERENSI:}

Almilia, L.S., \& Irmaya B. 2007. Faktor-Faktor Yang Mempengaruhi Kinerja Sistem Informasi Akuntansi Pada Bank Umum Pemerintah Di Wilayah Surabaya dan Sidoarjo. Jurnal. STIE Perbanas Surabaya.

Adisanjaya, K., \& Wahyuni, M.A. dan Purnamawati, I Gusti Ayu. 2017. Pengaruh Kemampuan Personal, Pelatihan dan Pendidikan Serta Pemanfaatan Teknologi Terhadap Efektivitas Sistem Informasi Akuntansi Pada Mini Market Bali Mardana. E-jurnal Akuntansi Universitas Pendidikan Ganesha. $7(1)$.

Brahmasari, I.A. 2004. Pengaruh Beberapa Variabel Budaya Perusahaan Terhadap Komitmen Karyawan dan Kinerja Perusahaan Kelompok Penerbitan Pers Jawa Pos. Disertasi.Universitas Airlangga. Pp: 121-122.

Chintya, I. 2015. Pengaruh Pemanfaatan Teknologi Informasi dan Sistem Pengendalian Intern Pemerintah terhadap Kinerja Instansi Pemerintah di Kota Solok (Studi pada SKPD Kota Solok).

Davis, F.D. 1989. Perceived Usefulness, Perceived Ease of Use, and Acceptance of Information System Technology. Management Information Systems Quarterly, 13(3), pp:319-339.

Dessler, G. 2006. Manajemen Sumber Daya Manusia. Jilid 1. Jakarta: PT. Indeks. 
Fisher, G Joseph, 1998, Contingency Theory, Management Control System and Firm Outcomes: Past Results and Future Directions, Behavioural Research in Accounting. Vol. 10

Ismail, N. A., \& King, M. 2007. Factors influencing the alignment of accounting information systems in small and medium sized Malaysian manufacturing firms. Journal of Information Systems and Small Business, 1(1), 1-20.

Ikhsan, Arfan dan Teddy Priantara, I.B. 2008. Sistem Akuntansi Perhotelan. Edisi Pertama. Universitas Diponegoro Yogyakarta: Graha Ilmu.

Indriantoro, N. dan Supomo, B. 2013.Metodologi Penelitian Bisnis. Yogyakarta: BPFE.

Irma Diana Putri. 2014. Pengaruh Kemampuan Teknik Personal, Program Pelatihan dan Pendidikan Pemakai, Insentif dan Partisipasi Manajemen pada Kinerja Penerapan Sistem Informasi Akuntansi. Skripsi. Jurusan Akuntansi Universitas Udayana..

Kashani, F. H., \& Shahsavarani, H. R. 2015. The Impact of Participative Management on the Performance of Tehran Regional Water Company' $\mathrm{s}$ Staff, 5(2), 63-70.

Kao, S., Kuo, L., Chen, L.H. \& Wang, T.Y. 1996. Improving productivity via technology and management, International Journal of Systems Science, 27 (3), pp. 315-322.

Khan, R. A. G., Khan, F. A., \& Khan, M. A. 2011. Impact of Training and Development on Organizational Performance. Global Journal of Management and Business Research, 11(7), 63-69.

Mahoney, T.A. 1963. The Job Management, Industrial Relations. Journal. Vol: 2. Pp: $97-110$

Meriewaty, D \& Setyani, A. 2005. Analisis Rasio Keuangan Terhadap Perubahan Kinerja Pada Perusahaan di Industri Food and Beverages Yang Terdaftar di BEJ. Akuntansi, 8(9), pp: 2-86.

Mooney, Ann. Michael Mahoney, and Barbara Wixom. 2008. Achieving Top Management Support in Strategi Technology Initiatives. Howe School Alliance For Technology Management, 12(2), pp: 1-3

Mulyana, Z.T, Christina V., Sunardi S.B. .2017. Pengaruh Sistem Informasi Akuntansi Manajemen Terhadap Kinerja Manajerial dengan Kompetensi Sumber Daya Manusia Sebagai Variabel Moderating (Studi pada Universitas Widyatama). Jurnal. Pp: 2252-3936. 
Murty, W.A, dan Hudiwinarsih G. 2012. Pengaruh Kompensasi, Motivasi dan Komitemen Organisasional terhadap Kinerja Karyawan Bagian Akuntansi. Jurnal STIE Perbanas, 2 (2), h:215-228.

Nasir, A., \& Ranti O. 2013. Pengaruh Pemanfaatan Teknologi Informasi dan Pengendalian Intern terhadap Kinerja Instansi Pemerintah (Studi Pada Satuan Kerja Perangkat Daerah Kabupaten Kampar). Jurnal. h: 1-14.

Nopalia, P.W.E., \& Dewi F. 2012. Pengaruh Penggunaan Informasi Akuntansi Manajemen dan Kepribadian Wirausaha Terhadap Kinerja Manajerial: Survei Pada Dealer Sepeda Motor di Kota Jambi. Jurnal Akuntansi Fakultas Ekonomi Universitas Jambi, 1 (1), h: 42-49.

Ozera, G., \& Yilmaz, E. 2011. Effect of Procedural Justice Perception, Budgetary Control Effectiveness and Ethical Work Climate on Propensity to Create Budgetary Slack. Business and Economics Research Journal, 2(4),1-18.

Palamountain, K.M., Baker, J., Cowan, E.P., Essajee, S., Mazzola, L.T., Metzler, M., Schito, M.L., Stevens, W.S., Young, G.J. \& Domingo, G.J. 2012. Perspectives on introduction and implementation of new point-of-care diagnostic tests, Journal of Infectious Diseases, p. 203.

Pfano, M., \& Beharry, A. 2016. The effect of modern office technology on management performance: Durban Westville. Problems and Perspectives in Management, 14(2). pp: 14-13

Raymond, L. and Pare, G. 1992. 'Measurement of Information Tecnology Sophistication in Small Manufacturing Business', Information Resourses Manajement Journal, 5 (2). pp. 4-16.

Robbins, S.P., .2008. Organizational Behavior, Elevent Edition, International Edition inc., San Diego State University, Upper Sanddle River, New Jarsey.

Satya Wirawan, Bima dan Sadha Suardikha, I. M. 2016. Faktor-Faktor Yang Mempengaruhi Kinerja Individual Pada Bank Perkreditan Rakyat Di Kabupaten Badung. E-Jurnal Akuntansi Universitas Udayana, 17(3),pp: 2302-8556.

Soudani, S. N. 2012. The Usefulness of an Accounting Information System for Effective Organizational Performance. International Journal of Economics and Finance, 4(5),pp: 136-145.

Sugiyono. 2016. Metode Penelitian Bisnis. Bandung: Alfabeta. 
Ni Komang Diana Pradasari dan Ida Bagus Dharmadiaksa. Pengaruh.....

Thompson, R. L., Higgins, C. A., \& Howell, J. M. 1991. Personal Computing: Toward a Conceptual Model of Utilization. MIS Quarterly, 15(1), pp: 1-25.

Wilayanti, N. W \& Dharmadiaksa I.B. 2016. Keterlibatan dan Kemampuan Teknik Personal pada Efektivitas Penggunaan Sistem Informasi Akuntansi. E-Jurnal Akuntansi Universitas Udayana, 15(2),pp: 1310-1337. 